\title{
MUSLIMAH COSMOPOLITAN LIFESTYLE: ANTARA SYARI'AT, TREND MASA KINI DAN KAPITALISASI AGAMA (Studi Budaya Pop Terhadap Pemilihan Putri Muslimah Indonesia)
}

\author{
1Inayatul Ulya, ${ }^{2} \mathrm{MSI}$ \\ ${ }^{12}$ Institut Pesantren Mathali'ul Falah Pati Jawa Tengah \\ Jl. Raya Pati - Tayu KM.20, Kedung, Purworejo, Kabupaten Pati, Jawa Tengah 59154 \\ E-mail: ulyain@yahoo.com
}

\section{Article History:}

Received: 2018-08-28; Received in revised form: 2018-10-11; Accepted: 2018-10-18; Available online: 2018-10-25

\begin{abstract}
This article analyzes the importance of the use of popular culture as a method in the study of Islam within the cosmopolitan muslimah lifestyle phenomenon, particullary in the contes of Putri Muslimah Indonesia (Miss Muslimah Indonesia). The use of popular culture method to understand the real intension of hijab observerance;wether for the purpose observing sharia or just follow the present trend, or religious capitalisation. The Observerance of sharia commonly interpreted by wearing of the so-called sharia clothing. Because wearing sharia clothing (hijab syar'i) as the symbol of religious piety and secondly, emphasizing that sharia in this case always adaptive in any circumstances as long as it doesn't violate the basic teaching of sharia, as the present demand of muslimah lifestyle is expressed in various way, one of them is the trend of hijab syar'i. Third, the utilization of religious symbol to generate economic profit. Various events such as the contes of Putri Muslimah Indonesia (Miss Muslimah Indonesia) as important booster for muslim fashion industries to gain huge profits by targeting large market of stylist cosmopolitan muslimah. Thus, the element of religious capitalization is much more visible than spreading the true spirit of Islamic teaching.
\end{abstract}

Keywords: Muslimah Cosmopolitan Lifestyle, Syaria, present trend, religious capitalisation

\begin{abstract}
Abstrak
Artikel ini menganalisa pentingnya penggunaan budaya populer sebagai metode dalam studi Islam dalam fenomena gaya hidup muslim kosmopolitan, khususnya dalam konteks Putri Muslimah Indonesia (Miss Muslimah Indonesia). Penggunaan metode budaya populer untuk memahami kehebatan nyata dari pengamatan jilbab, baik untuk tujuan mengamati syariah atau hanya mengikuti tren saat ini, atau kapitalisasi agama. The Observerance of syariah biasanya diartikan dengan mengenakan apa yang disebut pakaian syariah. Karena mengenakan pakaian syariah (jilbab syar'i) sebagai simbol kesalehan religius dan kedua, menekankan bahwa syariah dalam hal ini selalu adaptif dalam keadaan apa pun asalkan tidak melanggar ajaran dasar syariah, seperti tuntutan muslimah saat ini. Gaya hidup diungkapkan dengan berbagai cara, salah satunya adalah tren jilbab syar'i. Ketiga, pemanfaatan simbol agama untuk menghasilkan keuntungan ekonomi. Berbagai acara seperti kontes Putri Muslimah Indonesia (Miss Muslimah Indonesia) sebagai pendorong penting bagi industri mode muslim untuk mendapatkan keuntungan besar dengan menargetkan pasar besar muslimah kosmopolitan
\end{abstract}


stylist. Dengan demikian, unsur kapitalisasi agama jauh lebih terlihat daripada menyebarkan semangat sejati ajaran Islam.

Kata Kunci,: Muslimah Cosmopolitan Lifestyle, Syariat, Tren Sekarang, Kapitalisasi Agama.

\section{PENDAHULUAN}

Islam merupakan agama yang dinamikanya terus berkembang seiring dengan berubahnya waktu dan membawa keanekaragaman budaya. Keanekaragaman budaya tersebut disikapi sebagai bagian dari sensitivitas Islam dalam mengakomodir tradisi dan budaya yang berkembang di masyarakat dalam rangka menjaga nilai-nilai keharmonisan dan penghargaan terhadap keanekaragaman budaya masyarakat hingga menghasilkan toleransi dengan tetap memegang prinsip-prinsip dalam ajaran Islam itu sendiri.

Muslimah Cosmopolitan Lifestyle merupakan gambaran kehidupan muslimah yang hidup pada masyarakat urban, dilatarbelakangi oleh keinginan perempuan muslim untuk selalu tampil mempesona karena penampilan merupakan cerminan tingkat kebudayaan dan menjadi karakteristik khusus yang dapat memperindah hubungan personal maupun sosial di lingkup masyarakat lingkungan sosialnya. Beberapa fenomena yang menggambarkan gaya hidup muslimah kosmopolitan diantaranya pemakaian busana muslimah dengan berbagai mode, penyelenggaraan even-even tutorial hijab, peragaan busana muslimah dan sebagainya.

Dalam hal ini, tentu saja seorang muslimah tidak hanya memprioritaskan penampilan fisiknya saja. Karena bagi seorang muslimah, kecantikan itu tidak hanya ditunjukkan dengan kecantikan fisik dan balutan busana yang fashionable saja, tetapi juga ditentukan oleh keindahan kepribadiannya. Manajemen kepribadian yang maksimal melalui kesantunan bahasa, gerak-gerik perilaku simpatik, dan pola pikir yang cerdas dan up to date serta selalu mengembangkan talenta yang dimiliki turut memperkuat kecantikan seorang muslimah. Sehingga, gaya hidup atau lifestyle muslimah kosmopolitan, tentunya tidak bisa dipisahkan dari nilai-nilai keislaman, keperempuanan dan kemodernan. Maka, menjadi muslimah kosmopolit idealnya memiliki lifestyle yang khas dan memiliki kecantikan yang complicated karena tidak hanya cantik secara fisik tapi juga memiliki innner beauty yang menarik karena setiap langkahnya selalu mengaktualisasikan nilai-nilai kemodernan dan ke-Islaman.

Muslimah Cosmopolitan Lifestyle adalah bagian dari fenomena sosial dan budaya yang hadir pada era postmodern. Salah satu perkembangan budaya 
tentang gaya hidup muslimah kosmopolitan adalah munculnya sebuah kontes pemilihan Putri Muslimah indonesia. Sedangkan budaya popular digunakan sebagai pendekatan untuk memahami makna dibalik realitas yang terlihat, apakah motivasi sesungguhnya adalah mensyi'arkan syari'at Islam, mengakomodir trend masa kini atau ada nuansa kapitalisasi agama dibalik even Pemilihan Putri Muslimah Indonesia.

Beberapa penelitian tentang gaya hidup muslimah dan budaya popular sudah dilakukan melalui sisi yang berbeda diantaranya karya Sinung Utami Hasri Habsari tentang fashion hijab dalam kajian budaya populer. Penelitian tersebut menghasilkan temuan bahwa pemakaian hijab pada era modern telah mulai ada pergeseran dari spirit menjalankan ajaran agama menjadi style dalam berbusana (Habsari, 2015: 133). Sedangkan Retno Hendariningrum dan M. Edy Susilo meneliti tentang fashion dan gaya hidup: identitas dan komunikasi. Penelitian tersebut menemukan bahwa media mempunyai peran besar dalam mengkonstruksi khalayak agar tampil menarik, selain itu media juga berperan dalam menyebarkan gaya hidup public figure seperti selebriti (Hendariningrum \& Susilo, 2008:31). Perbedaan dengan artikel ini terletak pada kontentasi syari'at, trend masa kini dan kapitalisasi agama dalam even pemilihan putri muslimah Indonesia tahun 2017.

Pertanyaan mendasar dari tema ini adalah bagaimana muslimah mengakomodir syari'at dan trend masa kini dalam menentukan gaya hidup? Bagaimana pola keberagamaan perempuan pada era modern? Dan pertanyaan mendasar tentang Bagaimana kontestasi nilai syari'at, trend masa kini dalam even Pemilihan Putri Muslimah Indonesia?

\section{METODE}

Penelitian ini merupakan penelitian kualitatif dengan pendekatan budaya populer. Data diambil dengan cara observasi pada tayangan perhelatan malam puncak Putri Muslimah Indonesia 2017 pada tanggal 8 Mei 2017 di Televisi Indosiar. Analisis data menggunakan semiotika visual untuk mengungkap makna yang disampaikan melalui media indra yang terlihat kemudian diinterpretasi secara deskriptif kualitatif.

\section{Muslimah Cosmopolitan Lifestyle: Bentuk Akomodasi Syari'at dan Trend Masa Kini}

Muslimah adalah wanita Islam dan kosmopolitan adalah wawasan luas (KBBI,2016). Muslimah kosmopolitan adalah seorang muslimah yang 


\section{0 | Inayatul Ulya, MSI}

berwawasan global, kekinian namun tetap dengan cara syar'i, berdasarkan syari'at Islam yang berpedoman pada al-Qur'an dan Hadits (Dani, 2014: xii). Sedangkan lifestyle diartikan sebagai gaya hidup yang meliputi cara hidup sehari-hari, cara berpakaian dan menjaga kecantikan, cara bergaul dan berinteraksi dengan pihak lain, dan sebagainya.

Muslimah cosmopolitan lifestyle secara lebih luas dapat diartikan sebagai gaya kehidupan perempuan muslimah yang memiliki iman kuat, ilmu dan wawasan luas dibidang ilmu agama dan ilmu umum, berakhlak mulia, memiliki integritas mandiri dan percaya diri serta aktif dalam berbagai kegiatan di lingkungan sosialnya, berkontribusi dalam memajukan Islam dan masyarakat sekitar, berwawasan global, mengikuti gaya hidup masa kini namun tetap dengan cara dan gaya syar'i (Dani, 2016:1). Gambaran gaya hidup muslimah kosmopolitan ini beberapa hal diekspresikan dalam bentuk "bungkus luarnya saja". Misalnya maraknya pemakaian busana muslimah dan hijab syar'i pada muslimah di Indonesia dengan berbagai model dan trend masa kini yang lebih memperlihatkan kecantikan luar seorang perempuan. Meski hal ini diakomodir oleh syari'at, tetapi spirit menjalankan ketaatan menutup aurat dan menampilkan keindahan akhlaqul karimah seharusnya lebih menjadi prioritas.

Kecantikan adalah sesuatu keindahan yang melekat pada seorang perempuan, maka kecantikan adalah anugerah yang harus disyukuri, dijaga dan dirawat. Tentang menjaga kecantikan dan keindahan penampilan ini, dari sisi agama telah banyak memberikan jawaban dengan banyaknya ayatayat al-Qur'an yang berbicara tentang keindahan. Diantaranya al-Qur'an memerintahkan manusia untuk mengamati langit dan keindahannya (QS. Qaf: 6). Pada surat Ash-Shaffat:6 Allah juga menyatakan: “Bintang-bintang yang gemerlapan dijadikan Allah antara lain sebagai hiasan (QS. AshShaffat:6). Selain beberapa ayat tersebut, hadits Nabi Muhammad saw juga menyampaikan pesan kecantikan dan keindahan tersebut: "Innallaaha 
jamiilun yuhibbul jamaal”, yang artinya: "Sesungguhnya Allah itu indah dan menyenangi keindahan (kecantikan)" (HR. Muslim melalui Ibnu Abbas).

Dalam konteks kecantikan dan lifestyle tentu saja Islam menganjurkan untuk menyeimbangkan kecantikan lahir dan batin. Kecantikan lahir dapat diperoleh dari hal yang bersifat jasmani, melalui serangkaian perawatan kecantikan dan pakaian yang fashionable dan tetap menutup aurat. Sedangkan kecantikan batin atau disebut dengan inner beauty adalah kecantikan yang bersumber dari dalam berupa keimanan, ilmu pengetahuan, keterampilan, akhlak yang mulia.

Diantara perlunya kecantikan lahir dan batin tersebut sebagaimana diungkap Quraisy Syihab (2007: 65) dalam memaknai QS. Al-A'raf: 31 yang artinya: "Hai anak-anak Adam, pakailah pakaian kamu yang indah di setiap masjid". Ayat tersebut memerintahkan kita untuk tampil indah, bahkan ketika menghadap Allah di masjid. Masjid dalam arti bangunan untuk ibadah ritual maupun masjid dalam arti keindahan bangunan fisik. Maka dalam konteks tersebut, Allah menganjurkan perempuan untuk berdandan.

Secara spesifik, aturan berpakaian bagi perempuan diberi batasan tentang aurat yang harus ditutup. Ulama' bersepakat tentang kewajiban menutup aurat tersebut, tetapi ada perbedaan pendapat tentang batas aurat. Sebagian besar ulama' berpendapat bahwa perempuan berkewajiban menutup seluruh anggota tubuhnya. Sedangkan Abu Hanifah sedikit lebih longgar karena tidak hanya muka dan telapak tangan yang boleh terlihat, tetapi juga kaki juga boleh terbuka. Di sisi lain Abu Dakar bin Abdurrahman dan Imam Ahmad berpendapat bahwa seluruh anggota badan perempuan itu aurat yang harus ditutup (Shihab, 2007:215). Perbedaan pendapat tersebut secara umum karena perbedaan penafsiran QS. An-Nur ayat 31: "Dan janganlah mereka menampakkan perhiasannya kecuali yang tampak darinya". Tetapi di tengah perbedaan tersebut, secara umum perempuan mengikuti menutup aurat seluruh tubuhnya kecuali muka dan telapak 


\section{2 | Inayatul Ulya, MSI}

tangan. Maka dalam menunjang penampilan berpakaian perempuan, boleh saja menggunakan gaya berpakaian modern, bervariasi dan menggunakan pernak pernik lainnya asalkan tetap menutup aurat tersebut.

Selain dalam hal berpakaian, perempuan muslimah modern dengan berbagai perannya sebagai istri, ibu dan sebagai wanita karir selalu dituntut untuk berperan ganda (multi tasking). Tetapi peran ganda tersebut direspon oleh muslimah kosmopolitan sebagai media untuk selalu bersikap positif dan terus berkarya demi untuk kemajuan dirinya dan lingkungan sekitarnya. Pola fikir positif tersebut membuat seorang muslimah kosmopolitan terus ingin mengejar prestasi, meneguhkan perannya sebagai kholifah fil ardl (kholifah di bumi). Karena perempuan dan laki-laki diciptakan setara, sama-sama memiliki peran sebagai khalifah fil ardl tersebut. Sebagaimana pendapat Riffat Hasan (1991: 67-68) bahwa laki-laki dan perempuan telah diciptakan setara oleh Allah, maka dikemudian hari mestinya tidak berubah menjadi tidak setara. Oleh karena itu, jika ternyata dikemudian hari berubah menjadi tidak setara berarti menyalahi desain yang telah direncanakan oleh Allah.

Kajian normatif terhadap gaya hidup Islami ini diakomodir dalam Islam baik dari ayat-ayat al-Qur'an maupun Hadits Nabi. Diantaranya QS. An-Nisa: 86 yang artinya: "Apabila kamu dihormati dengan suatu (salam) penghormatan, balaslah penghormatan itu dengan yang lebih baik, atau balaslah penghormatan itu yang sepadan dengannya. Sungguh Allah memperhitungkan segala sesuatu" (QS. An-Nisa': 86).

Akhlak dalam hal ini memiliki arti yang sangat penting dalam memaksimalkan peran cantik seorang muslimah agar selalu dapat beradaptasi dengan lingkungan sosialnya. Akhlak merupakan pesona kecantikan seorang muslimah yang berasal dari dalam (inner beauty). Kecantikan akhlak ini dapat dilihat dari bagaimana cara seorang muslimah 
dalam bersikap ketika makan, minum, berpakaian, memberikan salam, berbicara, adab bepergian dan lain sebagainya.

Adab dalam berakhlak tersebut hendaklah mengacu pada Rasulullah Muhammad Saw sebagai Nabi dan Rasul sekaligus manusia yang telah sempurna akhlaknya sebagaimana dijelaskan dalam QS. Al-Qalam:4 bahwa: "sesungguhnya engkau benar-benar berbudi pekerti luhur". Ayat tersebut juga diperkuat dengan Surat Al-ahzab: 21 yang artinya: sungguh telah ada pada diri Rasulullah Saw itu teladan yang baik bagimu (QS. Al-Ahzab: 21).

Bagi seorang muslimah yang tidak hanya memiliki peran domestik di rumah sebagai istri dan ibu bagi anak-anaknya, Islam mengizinkan seorang perempuan untuk memiliki peran publik, bekerja di luar rumah dan mengaktualisasikan dirinya secara aktif di masyarakat, sebagaimana firman Allah dalam QS. An-Nahl: 97 yang artinya: "Barang siapa mengerjakan kebajikan, baik laki-laki maupun perempuan dalam keadaan beriman, pasti kami berikan kepadanya kehidupan yang baik dan Kami beri balasan dengan pahala yang lebih baik dari apa yang telah mereka kerjakan.

Ayat di atas mengakomodir perempuan untuk memiliki aktivitas publik secara Islami, tidak membedakan antara laki-laki dan perempuan, semuanya bagian dari ibadah yang kelak akan mendapatkan balasan pahala. Laki-laki maupun perempuan digambarkan oleh Allah memiliki potensi yang sama-sama bisa diberdayakan untuk dapat menghasilkan karya-karya terbaik.

Perempuan juga dipersilahkan bersosialisasi dengan pihak lain. Hal tersebut tergambar sebagai aktivitas silaturrahim sebagaimana dalam alQur'an QS. An-Nisaa:1 yang artinya: "Hai sekalian manusia bertawakkallah kepada Tuhanmu yang telah menciptakan kamu dari seorang diri, dan dari padanya Allah menciptakan istri, dan dari keduanya Allah memperkembangbiakkan laki-laki dan perempuan yang banyak. 


\section{4 | Inayatul Ulya, MSI}

Bertawakkallah kepada Allah yang dengan (mempergunakan) nama-Nya kamu saling meminta satu sama lain, dan (peliharalah) hubungan silaturrahim. Sesungguhnya Allah selalu menjaga dan mengawasi kamu”.

Seiring dengan perkembangan zaman, seakan menjadi tantangan tersendiri bagi muslimah. Di satu sisi muslimah dituntut untuk selalu tampil modern dan up to date, tapi di sisi lain juga harus pandai menfilter dengan konsep dirinya sebagai perempuan muslim serta tuntutan untuk selalu menjadi muslimah yang taat kepada ajaran agamanya. Sehingga gaya hidup muslimah kosmopolitan dalam hal ini harus membekali diri dengan karakter, adab dan akhlak yang Islami sebagai modal awal untuk beradaptasi dengan lingkungannya dan tidak terjebak arus yang justru bertentangan dengan syari'at Islam. Artinya muslimah kosmopolitan diposisikan untuk dapat selalu kooperatif dengan perkembangan zaman namun tetap taat mengikuti syariat Islam sesuai tuntunan di dalam alQur'an dan Hadist. Tujuannya agar para Muslimah tetap dapat bersosialisasi dan mengaktualisasikan dirinya dalam kehidupan sekarang, tanpa mengabaikan jati dirinya sebagai seorang muslimah yang sejati.

\section{Budaya Populer dan Pergeseran Keberagamaan Perempuan Modern}

Budaya populer atau dikenal dengan sebutan budaya pop berasal dari pemikiran post modernisme ${ }^{1}$ yang menolak pembedaan budaya pop dan budaya elit atau tinggi. Dalam hal ini, postmodernis menyatakan semua budaya adalah budaya postmodern. Lebih lanjut, postmodernis juga menganggap bahwa semua budaya adalah komersial, maka mereka tidak

\footnotetext{
${ }^{1}$ Post modernisme merupakan aliran pemikiran dalam filsafat yang menekankan pada kesetaraan,humanis-sekular, dualisme, anti otoritas, hukum Islam relatif, anti universalisme, menolak pengetahuan non-empiris dan pluralisme. Post modernisme ini pada awalnya muncul sebagai bentuk reaksi penolakan terhadap modernisme (Hasan, 2011: 90).
} 
memperdulikan otentitas budaya daerah sebagai budaya yang harus dipelihara dan dipertahankan (Storey, 2003: 10-22).

Budaya pop berarti kebudayaan rakyat. Menurut bahasa latin kata ini lebih merujuk pada kebudayaan yang berkembang dari kreativitas kebanyakan orang. Budaya pop berasal dari rakyat dan bukan diberikan kepada mereka. Perspektif ini sekaligus mematahkan pembedaan antara produsen dan konsumen artifak budaya, pembedaan antara industri budaya dan konteks penerima yang dianggap memproduksi budaya pop (Lull, 1998 : 85).

Berbeda dengan pendapat di atas, John Fiske memahami budaya populer sebagai komoditas yang membawa kepentingan-kepentingan masyarakat. Budaya populer diciptakan oleh masyarakat dan tidak diciptakan oleh industri budaya. Industri budaya kapasitasnya hanya menciptakan sumber daya budaya untuk kemudian diterima atau ditolak masyarakat sebagai proses yang berkesinambungan dalam menciptakan budaya populer mereka (Fiske, 2011: 25-26). Dalam hal ini, budaya populer tidak dapat tercipta dengan sendirinya, karena terbentuk atau tidaknya sebuah budaya ditentukan oleh hasrat masyarakat setempat dan diharapkan mampu menyesuaikan dengan kebutuhan masyarakat sehingga budaya tersebut dapat diterima dan dijaga keberlangsungannya.

Budaya populer dalam konteks fenomena sosial yang berkembang dalam masyarakat dapat difahami pada hal berikut:

Pertama, budaya popular merupakan budaya yang menyenangkan atau banyak disukai orang karena budaya pop kelahirannya merupakan inisiasi dari masyarakat, sehingga masyarakat memiliki kebebasan untuk berekspresi tanpa harus terbengkalai dengan eksklusivitas. 
Kedua, budaya pop diciptakan dari dan untuk masyarakat. Dalam hal ini budaya pop lahir dari keinginan masyarakat dan diterima masyarakat sebagai sebuah budaya baru yang sedang dibutuhkan pada saat itu.

Ketiga, budaya pop merupakan sunnatullah yang dapat sangat fenomenal pada masanya dan tenggelam di masa mendatang tergantung bertahan atau tidaknya penerimaan masyarakat, karena kalau dikaji lebih detail bahwa budaya pop mayoritas didominasi oleh kelompok dominan dan menciptakan hegemoni pada kelompok subordinat. Secara natural, budaya pop ini keberlangsungannya akan di uji oleh waktu.

Begitu pula dengan pola keberagamaan perempuan juga mengalami pergeseran dari waktu ke waktu sesuai dengan perkembangan peran dan fungsi perempuan. Berbagai aspek yang terkait dengan perempuan, termasuk dalam hal peran dan fungsi perempuan dalam masyarakat secara tidak sadar terjadi karena konstruksi budaya ${ }^{2}$, atau paling tidak budaya memiliki kontribusi besar dalam membentuk persepsi mengenai peran dan fungsi perempuan dalam kehidupan.

Budaya Arab pra Islam menggambarkan kondisi perempuan masih didominasi kaum laki-laki dalam peran sosial, politik dan ekonomi. Tetapi ketika Islam datang, Nabi Muhammad sebagai figur suri tauladan tidak pernah memperlakukan istrinya sebagai konco wingking, tetapi memerankan mereka sebagai partner dalam mengatasi berbagai tantangan hidup (Hamim, 2002: xxviii). Seperti diketahui bahwa Khodijah adalah penasehat utama nabi yang selalu memberikan advokasi, setiap kali nabi menghadapi situasi kritis. Melalui kemampuan lobinya, upaya kelompok

\footnotetext{
${ }^{2}$ Kebudayaan dalam hal ini merupakan suatu proses dialektika antara berbagai sistem dalam masyarakat, beberapa sistem dalam masyarakat tersebut seperti sistem kepercayaan, sistem kekuasaan, sistem ekonomi, sistem sosial, sistem pendidikan, sistem bahasa, sistem kesenian dan lain-lain. Sistem-sistem tersebut berdialektikasampai tercapai sintesa berbagai sistem budaya tersebut sehingga membangun sosok budaya baru (Kayam dalam Bainar (ed.), 1998: 37).
} 
elit Mekkah untuk mengganjal perjuangan nabi di kota itu selalu dapat digagalkan (Ashfar, 1996: 1999). Peran serupa juga ditemukan pada diri A'isyah, yang tidak hanya mendampingi nabi dalam berbagai ekspedisi militernya, tetapi juga menjabarkan ajarannya. A'isyah dikenal sebagai seorang transmitter (al-rawiyah) terkemuka hadits nabi (Ashfar, 1996: 1999). Dengan modal pengalaman sebagai aktivis lapangan semasa mendampingi nabi, A'isyah kemudian mampu membentuk kekuatan oposisi untuk menentang pemerintahan Ali dalam perang Jamal. Peran A'isyah tersebut dapat menggambarkan keterlibatan perempuan dalam peran publik pada masa awal Islam.

Peran perempuan banyak mengalami pergeseran-pergeseran mulai pada era globalisasi. Kalau masa lampau, terkesan perempuan hanya menjadi obyek perhatian kaum laki-laki dibidang kebutuhan biologis dan tidak memiliki peran yang mengarah pada progresivitas manusia. Namun lambat laun, sosok wanita mendapat perhatian tersendiri dan menjadi sosok manusia yang dihargai perannya.

Pada era kontemporer yang sarat dengan perkembangan dan pertumbuhan Ilmu Pengetahuan dan Teknologi, sosok wanita tidak dipandang sebelah mata dalam kiprahnya diberbagai bidang kehidupan. Karena pada dasarnya perempuan dan laki-laki sama baik kecerdasan otaknya, kemuliaan budi, keluhuran cita-cita, memiliki impian dan harapan, kekhawatiran dan ketakutan begitu pula potensi untuk memimpin (Tan, 1991:13). Dan atas dasar itulah perempuan dan laki-laki memiliki kesempatan yang sama dalam memanfa'atkan potensinya masing-masing, meskipun dalam tatanan praktis, perempuan harus berjuang beberapa kali lebih keras dibanding laki-laki untuk memperoleh sebuah kesetaraan.

Sebuah kasus dapat diungkap dari seorang profesional perempuan di bidang jusnalistik, menyatakan: "saya merasa perempuan harus berjuang dua tiga kali lebih keras untuk menempati posisi struktural di kantor saya" 


\section{8 | Inayatul Ulya, MSI}

(Kompas, 2003). ${ }^{3}$ Kasus tersebut mungkin hanya sedikit dari kasus-kasus yang terekspose tentang masih terasanya diskriminasi terhadap perempuan. Mungkin hal tersebut merupakan sisa-sisa sistem patriarkhi yang sekian lama menyatu dengan sistem sosial dan kultural di masyarakat. Tetapi minimal usaha penyetaraan peran laki-laki dan perempuan sudah banyak terlihat misalnya dalam konteks negara Indonesia dengan memberikan kuota 30 \% bagi keterwakilan perempuan di gelanggang politik. Meskipun dalam realita tidak berjalan secara maksimal.

Dikalangan umat Islam, muncul fenomena yang menginginkan adanya perubahan pada teks fiqh konvensional yang dianggap membelenggu kaum wanita dalam mengembangkan perannya demi tercapainya progresivitas umat Islam diberbagai sektor kehidupan secara makro (Dewantoro, 1996: 6). Dalam hal ini penulis sepakat dengan ungkapan Amina Wadud bahwa pada dasarnya, bukan ayat-ayat al-Qur'an yang membatasi kaum perempuan, namun penafsiran atas nash tersebut yang menyebabkan munculnya pemahaman sempit terhadap hak-hak kaum perempuan (Muhsin, 1994: 118-119).

Berdasarkan hal di atas menegaskan bahwa pergeseran peran perempuan terkait dengan perkembangan budaya yang berubah dari waktu ke waktu dan setiap sistem budaya terbentuk berdasarkan hal mendasar tentang pandangan dan pola fikir dalam menerjemahkan ayat al-Qur'an sebagai pedoman ajaran Islam dan selanjutnya produk pemahanan tersebut diaplikasikan dalam realitas kehidupan (Abusulayman, 2011: 1).

\footnotetext{
${ }^{3}$ Peran perempuan di ranah publik sudah banyak ditemukan, misalnya di rumah sakit, bank, sekolah, universitas dan lain-lain. Tapi, di tempat-tempat tersebut belum banyak yang terlihat dalam posisi pengambil keputusan (Mai Yamani, 2007: 350). Dalam konteks ini, diperlukan peningkatan kualitas sumber daya kaum perempuan melalui pendidikan, sehingga kesetaraan peran antara laki-laki dan perempuan akan dapat diwujudkan. Ketika kualitas SDM perempuan tersebut belum sejajar, maka akan jarang ditemukan perempuan untuk menempati posisi-posisi strategis di masyarakat (Kurniawaty, Lia dalam Anshori, Dadang S (at all.), 1997: 53).
} 
Mengikuti perkembangan masa kini muslimah cosmopolitan lifestyle merupakan gambaran gaya hidup seorang muslimah modern yang berwawasan global, open mind terhadap setiap perubahan mengikuti gaya hidup modern namun dengan cara dan gaya tetap syar'i. Sehingga muslimah kosmopolitan menggambarkan tentang muslimah masa kini yang selalu terbuka pemikirannya, anggun pribadinya, menarik penampilannya, memahami secara utuh peran domestik dan sosialnya serta berkontribusi positif bagi masyarakat sekitarnya. Sebuah istilah yang tepat untuk mendeskripsikan muslimah kosmopolitan adalah muslimah yang mengikuti pergeseran budaya kekinian yang cantik luar dalam atau muslimah yang cantik lahir dan batin. Muslimah kosmopolitan menampilkan sebagai muslimah yang berpegang teguh pada keimanan, ilmu dan wawasan yang luas dan matang tentang Islam dan umum, memiliki integritas tinggi, berakhlak mulia, mandiri, percaya diri, dan berkontribusi secara aktif di lingkungan sekitarnya demi untuk memajukan Islam dan masyarakat secara luas.

Muslimah cosmopolitan lifestyle mencirikan sebuah jati diri gaya hidup perempuan muslim untuk selalu berfikir positif, visioner, selalu berkarya dan mengejar prestasi. Seluruh kegiatan yang dilakukan sematamata untuk menggapai ridha Allah. Dalam konteks ini, muslimah kosmopolitan selalu mengutamakan pendidikan dan pandai menempatkan diri dalam lingkungannya serta dapat berinteraksi dan bersosialisasi dalam lingkungannya. Muslimah kosmopolitan juga dapat memerankan dirinya dengan baik sesuai dengan ajaran Islam dalam posisinya sebagai istri kepada suaminya, ibu kepada anaknya dan dapat memainkan peran publiknya di masyarakat dengan baik bahkan dapat menjadi inspirasi kepada muslimah lain dan masyarakat di sekitarnya. 


\section{Pemilihan Putri Muslimah Indonesia sebagai Budaya Pop Muslimah Masa Kini}

Munculnya banyak fenomena tentang budaya popular khususnya di Indonesia mengindikasikan bahwa ada banyak varian produk budaya populer yang sering kita saksikan dan menjadi mainstream dalam kehidupan sehari-hari, di-ekspose di media elektronik maupun cetak dengan karakteristik khas perempuan, diantaranya adalah Pemilihan Putri Muslimah Indonesia. Beberapa hal berikut terkait informasi tentang kontes Putri Muslimah Indonesia yang peneliti dapatkan dari hasil observasi pada tayangan perhelatan malam puncak Putri Muslimah Indonesia 2017 pada tanggal 8 Mei 2017 di Televisi Indosiar.

Ajang Pemilihan Putri Muslimah Indonesia merupakan sebuah ajang yang diperuntukkan bagi para wanita muslim (muslimah) untuk tampil menunjukkan bakat serta kemampuan yang dimiliki oleh mereka dalam berbagai bidang. Tidak hanya memperhatikan bagaimana sisi kecantikan seorang muslimah tampil di khalayak umum atau media, tetapi di ajang ini, para finalis terpilih akan mendapat gemblengan atau bekal selama mengikuti karantina untuk lebih menggali potensi kreatifitas dalam diri mereka tentunya sebagai seorang muslimah, yakni memperhatikan akhlak, etika dan menjaga image seorang putri muslimah yang tak hanya cantik dari luar tetapi juga dari dalam (inner beauty).

Kontes Putri Muslimah Indonesia ini dilatarbelakangi oleh maraknya ajang pencarian bakat di Indonesia namun dengan banyaknya mayoritas penduduk muslim khususnya muslimah Indonesia yang berhijab belum memiliki wadah untuk dapat ikut berpartisipasi dan mengapresiasikan diri sehingga bisa memberikan warna baru dalam dunia hiburan. Ajang ini dikemas sebagai sebuah kontes untuk memilih sosok wanita muslim yang mempresentasikan karakter muslimah sejati (Republika, 28/04/06). Ajang ini berbeda dari ajang Miss Indonesia atau Putri Indonesia, karena pemenangnya tidak akan berlanjut untuk mengikuti ajang Internasional 
manapun. Namun lebih ditugaskan untuk kegiatan sosial seperti memberi bantuan atau santunan kepada masyarakat kurang mampu serta mengemban misi untuk mengharumkan Agama Islam. Tak hanya itu, pemenang juga nantinya dikontrak oleh Stream Entertaiment.

Ditengah ramainya pemberitaan Miss Universe yang masih pro dan kontra dikalangan muslimah sendiri, Pemilihan Putri Muslimah Indonesia (Miss Muslimah) hadir dengan menampilkan fashion khas muslimah Indonesia. Sisi positif yang bisa didapatkan dapat mengangkat fashion muslimah sebagai bagian dari budaya muslim di Indonesia. Pemilihan Putri Muslimah Indonesia dapat menjadi media untuk menjaring ribuan muslimah agar berpartisipasi dalam menunjukkan prestasi dengan identitas kemuslimahannya. Beberapa kriteria atau syarat untuk mengikutinya adalah; wanita muslimah, single, belum menikah, usia 17-25 tahun, berpenampilan menarik, tinggi minimal 165 sentimeter, memiliki bakat di bidang akting, tarik suara, modelling, presenting dan bakat lainnya, bisa membaca Al-quran dan tentunya berhijab/berjilbab. Bagi putri yang terpilih akan menjadi sosok duta yang akan merepresentasikan figur muslimah Indonesia yang berprestasi, bertalenta dan berkepribadian Islami.

Ajang miss muslimah ini diperuntukkan untuk kaum muslimah menggunakan tiga kriteria utama dalam penilaiannya. Kriteria penilaian tersebut dapat dilihat dari segi akhlak, bakat, dan cantik, atau dikenal dengan istilah $\mathrm{ABC}$. Komponen tersebut dianggap menjadi kunci dalam kehidupan seorang wanita muslim. Akhlak menjadi kriteria utama yang dijadikan penilaian karena dianggap sebagai kunci dalam kehidupan. Akhlak ini menempati posisi yang sangat penting bagi seorang muslimah. Sehingga, sehebat apapun, seorang muslimah tidak akan dihargai apabila tidak memiliki akhlak yang baik. Kehalusan budi pekerti, sikap jujur, dan berbagai perilaku terpuji lain akan tercermin dalam attitude seseorang. 


\section{2 | Inayatul Ulya, MSI}

Kriteria cantik menjadi komponen terakhir yang dinilai dalam ajang ini. Kecantikan ini diposisikan sebagai penyempurna penilaian terhadap seorang kontestan. Penilaian tidak hanya dalam hal fisik, namun juga dilihat dari inner beauty, cara berpenampilan, cara mengambil sikap dan keputusan pada suatu keadaan. Komponen tersebut akan menjadikan seorang muslimah akan sempurna dalam kehidupannya. Berbekal akhlak yang terpuji, maka talenta juga akan semakin terlihat. Artinya, seseorang yang memiliki akhlak terpuji akan semakin sempurna dengan talenta yang dimiliki.

Kontes Putri Muslimah Indonesia juga disponsori oleh beberapa produk kecantikan, perancang busana, beberapa produk iklan pada tayangan televisi serta Korea Tourism Organization Jakarta (KTO Jakarta) memberikan hadiah menarik bagi pemenang utama, Runner up 1 dan Runner up 2. Hadiah yang diberikan berupa paket wisata ke Korea. KTO Jakarta akan mengirim ketiganya berkunjung ke Korea untuk melihat langsung budaya Korea. Direktur KTO Jakarta, Harry OH Hyonjae turut hadir pada acara malam puncak Putri Muslimah Indonesia dan menyerahkan hadiah langsung secara simbolis kepada para pemenang tersebut.

Kontes Putri Muslimah Indonesia merupakan fenomena yang muncul sebagai ekspresi keberagamaan perempuan masa kini yang tetap menjunjung tinggi nilai-nilai ke-Islaman, akhlak yang mulia dan talenta masing-masing dengan performa yang lebih up date dalam hal penampilan dan balutan fashion muslimah sehingga perempuan muslimah terlihat cantik lahir batin. 


\section{Studi Budaya Popular Pemilihan Putri Muslimah Indonesia: Kontestasi Syari'at, Trend Masa Kini dan Kapitalisasi Agama}

Studi terkait Pemilihan Putri Muslimah Indonesia menggunakan metode budaya popular sebagai salah satu metode dalam studi Islam diperlukan untuk memahami pemahaman yang utuh dari berbagai sudut yang ditampilkan produk budaya populer itu sendiri. Hal itu diperlukan untuk memahami makna dibalik realitas yang tampak melalui penelusuran langsung pada pelaku-pelaku budaya tersebut karena kerangka kerja fenomenologi menempatkan ilmu sosial dan budaya mencakup arti dan kemauan manusia, maka diperlakukan teknik atau metode pemahaman khusus. Mengungkap makna dibalik produk budaya populer tersebut diperlukan karena pembacaan terhadap budaya pop hendaklah dilakukan secara mendalam berdasarkan konteks sejarah, sosial, politik yang melingkupi produksi dan konsumsi kebudayaan, bahkan kemungkinankemungkinan terkait adanya perang ideologi juga sangat kental. Misalnya perang antara ideologi Kejawen, Islam, Liberalisme dan Marxisme dalam membingkai perdebatan produksi dan konsumsi budaya pop (Heryanto, 2012: 5).

Beberapa hal yang dapat dibaca dari fenomena Pemilihan Putri Muslimah Indonesia diantaranya dapat dipetakan menjadi tiga pola pemikiran sebagai berikut:

1. Pemilihan Putri Muslimah Indonesia merupakan media untuk mensyi'arkan Islam.

Pemilihan Putri Muslimah Indonesia merupakan acara yang cukup menarik masyarakat untuk menyaksikan langsung maupun melihat tayangannya di media televisi. Acara yang bertajuk kontes tersebut menyampaikan pesan yang cukup mendidik bahwa sesuai dengan syari'at Islam, perempuan tidak lagi hanya dilihat dari aspek fisiknya semata, tetapi kecantikan akhlak, sikap, talenta, dan 


\section{4 | Inayatul Ulya, MSI}

kecerdasan dalam menjawab pertanyaan dewan juri adalah sisi menarik yang ditampilkan dalam kontes tersebut. Selain itu, balutan busana yang Islami dan menutup aurat juga simbol yang mengungkapkan tentang kewajiban menutup aurat bagi seorang muslimah dalam kehidupan sehari-hari sesuai dengan ajaran Islam terutama tentang kewajiban menutup aurat bagi perempuan sesuai dengan ajaran dalam Surat An-Nur ayat 31. Sehingga melalui ajang Pemilihan Putri Muslimah Indonesia dapat menjadi media untuk mensyi'arkan Islam.

2. Pemilihan Putri Muslimah Indonesia merupakan salah satu lifestyle muslimah kosmopolitan yang mengikuti trend masa kini.

Sisi lain yang ditampilkan pada ajang Pemilihan Putri Muslimah Indonesia adalah tampilan fashion yang mengikuti trend masa kini. Selain itu, peran perempuan yang semakin terlihat pada area publik. Muslimah yang baik tidak hanya untuk perempuan yang dominan pada peran domestiknya, tetapi juga kiprahnya pada sektor publik dengan memberi kemanfaatan untuk kemaslahatan umat manusia. Hal ini memberi gambaran bahwa Islam tidak anti terhadap kemajuan zaman dan perkembangan budaya. Pergeseran peran perempuan di era modern ini untuk cantik secara lahir melalui tampilan fashion yang menarik dan cantik secara batin dengan menampilkan ketinggian akhlak yang mulia, kecerdasan, talenta dan kiprahnya dalam kehidupan sosial merupakan hal yang diakomodir oleh Islam dalam mendukung kesetaraan bagi perempuan dalam kehidupan modern.

3. Pemilihan Putri Muslimah Indonesia merupakan produk budaya populer yang terindikasi nuansa kapitalisasi agama.

Banyak fenomena yang menunjukkan agama digunakan untuk meraih keuntungan finansial. Berbagai even yang digelar diantaranya ada celah bisnis yang direncanakan akan lekat dibalik tujuan untuk mensyi'arkan Islam. Pemilihan Putri Muslimah Indonesia merupakan 
salah satu bentuk produk budaya popular yang mendorong industri menciptakan pasarnya, baik dalam hal produk kecantikan, asesoris dan fashion. Lemahnya daya kritis pasar berimplikasi pada masyarakat untuk terjebak mengikuti arus budaya konsumerisme. Budaya konsumerisme dapat menjadikan masyarakat kehilangan identitas dirinya dan membuat masyarakat untuk selalu mengikuti trend dan mengkonsumsi diluar kebutuhan hidupnya.

Fashion memang diciptakan oleh kapitalisme sebagai komoditas. Hal yang terlihat pada even Pemilihan Putri Muslimah indonesia memperlihatkan berbagai bentuk simbol agama yang diangkat ke ranah budaya pop. Misalnya, mengangkat fashion budaya muslim di Indonesia tidak semata-mata berupaya untuk memperkenalkan fashion Islami, tetapi dibalik itu ada tujuan terselubung yang tidak lepas dari tuntutan pasar. Simbol-simbol agama menjadi perdagangan. Parahnya, bukan hanya bentuk artefak seperti model, warna, dan corak saja, namun wacana berupa standar muslimah ideal seperti bisa membaca Al-Qur'an, kontes menjadi da'i yang handal, menguasai bahasa asing, dan mungkin kecantikan juga menjadi tujuan komoditas. Sehingga, kontes seperti pemilihan putri muslimah Indonesia juga merupakan bentuk reproduksi dan imitasi dari kontes Miss Universe, putri Indonesia dan sejenisnya yang notabene menjadi alat komoditas industri. Hal tersebut membawa style baru bagi masyarakat tentang cara berbusana, khususnya cara berjilbab, sudah berganti secara besar-besaran, dari yang sederhana dan simple menjadi lebih unik dan kompleks. Kecenderungan yang muncul adalah nuansa komersil yang mendatangkan keuntungan material. Kecenderungan komersialitas budaya berjilbab serta memberikan kesempatan besar bagi para desainer untuk menunjukkan rancangan kreatif jilbab mereka. Di lain pihak, antusiasme masyarakat dalam menyambut kehadiran model-model 
jilbab yang unik dan khas menjadi faktor utama meluasnya pemakaian jilbab modern ini.

Kajian budaya berdasarkan beberapa pendekatan yang digunakan akan dapat memahami makna yang sebenarnya dari setiap fenomena yang diangkat. Kritik terhadap budaya popularpun bermunculan. Kritik tersebut, diantaranya memandang ada ketidaksinkronan antara tujuan yang sebenarnya dengan apa yang ditampilkan diluar, misalnya ada yang berpandangan bahwa budaya pop, hijab populer bisa menjadi sesuatu yang dilarang, karena secara material terlihat berhijab, tetapi secara maknawi, esesnsinya tidak berhijab (Fadhlullah, 2000: 123). Ketika budaya telah bergeser menjadi sebuah kepentingan industri maka budaya yang bersangkutan akan lebih dominan merepresentasikan modernitasnya. Sementara konsep-konsep budaya modernitas itu sendiri tidak bisa menolak hadirnya ideologi kapitalisme liberal. Dalam konteks ini budaya kapitalisme liberal lebih di maknai atas nilai materialnya daripada nilai spiritualnya. Maka dari itu tidak heran jika teori-teori yang di pakai untuk menganalisis lebih banyak menggunakan teori-teori post modern. Namun demikian keberadaan teori-teori tersebut tidak mampu menyatukan budaya tinggi dan budaya rendah (popular) dalam perspektif kajian budaya seperti fenomena yang terjadi selama ini.

Pemilihan Putri Muslimah Indonesia selain dimaknai sebagai ajang untuk syi'ar Islam dan akomodasi budaya modern juga ada sisi lain yang perlu diwaspadai. Diantaranya adalah persekutuan dengan dunia industri hiburan dengan tujuan keuntungan finansial. Pencerahan pemaknaan dari kaum akademisi melalui produk-produk penelitian budaya sangat diperlukan untuk memahami makna dibalik realitas fenomena budaya pop yang banyak bermunculan, karena 
konsumsi budaya pop pada lingkup masyarakat awam akan bergerak apa adanya seperti apa yang terlihat saja, sedangkan para intelektual, pimpinan politik, penggerak moral dan sosial seringkali memiliki perspektif yang berbeda (Strinarti, 1995:41). Sehingga pembacaan budaya pop yang menjadi mainstream di masyarakat sering menjadi bahan kontroversi karena masing-masing memiliki perspektif yang berbeda sesuai dengan kepentingannya masing-masing.

\section{PENUTUP}

Islam dan ekspresi keberagamaan pemeluknya merupakan wajah baru Islam yang kehadirannya terus berkembang mengikuti perkembangan zaman. Berbagai fenomena baru selalu hadir silih berganti dan membutuhkan kajian studi Islam secara spesifik untuk dapat memberikan pengamatan yang lebih objektif, sehingga dapat memberikan pencerahan bagi umat Islam dalam menjalani hidup di era modern ini. Sebuah prinsip yang tetap harus dipegang adalah bahwa Islam adalah sebuah agama yang memiliki seperangkat aturan yang tetap harus dipegang teguh oleh ummatnya sekaligus adaptif terhadap setiap perubahan yang ada. Muslimah Cosmopolitan Lifestyle adalah salah satu ekspresi keberagamaan muslimah modern dalam mengokomodir syari'at Islam dan tuntutan trend masa kini. Kajian terhadap budaya populer merupakan salah satu pendekatan studi Islam yang akan dapat membongkar banyaknya fenomena yang muncul di permukaan, diantaranya adalah even Pemilihan Putri muslimah Indonesia, sehingga dapat dibedakan mana unsur syari'at, keharusan akomodatif terhadap budaya dan kapitalisasi agama yang cenderung menjadikan agama sebagai alat untuk mendatangkan keuntungan finansial. 


\section{DAFTAR PUSTAKA}

Abusulaiman, Abdulhamid, 2011, The Qur'anic Worldview: a Springboard for Cultural Reform, London: The International Institute of Islamic Thought Ashfar, Haleh, 1996, Islam and Feminism : An Analysis of Political Strategies, dalam Mai Yamani, (ed) Feminism and Islam : Legal and Literary Perspectives, New York : New York University Press

Dani, Indriya R, 2014, Muslimah Cosmopolitan Lifestyle, Bandung: PT. Remaja Rosdakarya

Endraswara, Suwardi, 2003, Metodologi Penelitian Kebudayaan, Yogyakarta: UGM Press

Fadhlullah, Husain, Muhammad, Sayid, 2000, Dunia Wanita dalam Islam, Jakarta: PT. Lentera Basritama

Fiske, John, 2011, Memahami Budaya Populer, Yogyakarta: Jalasutra

Habsari, Sinung Utami Hasri, 2015, Fashion Hijab dalam Kajian Budaya Populer, Jurnal PPKM II (2015), ISSN: 2354-869X

Hamim, Thoha, dalam Munhanif, Ali (ed)., 2002, Perempuan dalam Literatur Islam Klasik, Jakarta : PT. Gramedia Pustaka Utama

Hasan, Riffat, 1991, The Issue of Women : Men Equality in Islamic Tradition, New York : Gren Wood Press

Hendariningrum, Retno \& Susilo, M. Edy, 2008, Fashion dan Gaya Hidup: Identitas dan Komunikasi, Jurnal Ilmu Komunikasi, Volume 6 Nomor 2, Mei-Agustus 2008

Heryanto, Ariel (ed.), 2012, Budaya Populer di Indonesia, Yogyakarta: Jalasutra

Kamus Besar Bahasa Indonesia Luar Jaringan (Luring)," KBBI Offline Versi 1.5, http://kbbi-offline.googlecode.com/files/kbbi-offline-1.5.zip, didownload tanggal 12 November 2015

Kayam, Umar, dalam Bainar, Hj. Dr. (ed.), Wacana Perempuan: dalam Keindonesiaan dan Kemodernan, Yogyakarta: PT. Pustaka Cidesindo

Kompas, Senin 03 Maret 2003

Kurniawaty, Lia dalam Anshori, Dadang S (at all.), 1997, Membincangkan Feminisme, Bandung: Pustaka Hidayah

Lull, James., 1998, Media, Komunikasi, Kebudayaan : Suatu Pendekatan Global, Penerbit : Yayasan Obor Indonesia

Muhsin, Wadud, Amina, 1994, Wanita Dalam al-Qur'an, Bandung : Pustaka Amin Wadud-Muhsin, 1992, Qur'an and Women, Kuala Lumpur : Fajar Bakti Maliki, Zainuddin, 2004, Narasi Agung, Surabaya: LPAM

Shihab, Quraisy, M., 2007, Wawasan al-Qur'an, Bandung : Mizan 
2007, Perempuan: Dari Cinta sampai Seks, Dari Nikah Mut'ah sampai Nikah Sunnah, Dari Bias Lama sampai Bias Baru, Jakarta: Lentera Hati

Strinati, Dominic, 1995, an Introduction to Theories of Popular Culture, London:Routledge

Storey, John, 2003, Teori Budaya dan Budaya Pop, Yogyakarta: Qalam

Tan, Melly G., 1991, Perempuan Indonesia Pemimpin Masa Depan, Jakarta : Sinar Harapan

Yamani, Mai, 2007, Menyingkap Tabir Perempuan Islam, Bandung: Penerbit Nuansa 
120 | Inayatul Ulya, MSI

Halaman ini sengaja dikosongkan 